\title{
Rancang-Bangun Aplikasi Pengenalan Penyakit Berbasis Android Menggunakan Metode Naïve Bayes
}

\section{The Development of Android Based Illness Recognition Aplication Using Naïve Bayes Method}

\author{
W Zarman ${ }^{1 *}$, D Yuliawardhani ${ }^{2}$ \\ 1,2) Program Studi Sistem Komputer, Fakultas Teknik dan Ilmu Komputer, Universitas Komputer Indonesia \\ Jl. Dipati Ukur No. 112 - 116, Bandung, Indonesia 40132 \\ e-mail:wendi.zarman@email.unikom.ac.id
}

\begin{abstract}
Suffering from illness is a common problem in human life. When suffering from illness, someone usually goes to see a doctor for information of the illness. However, for several reasons such as cost, time, distance, or others, many people who are suffering from illness cannot see a doctor. This research is an effort to provide an alternative for people who have problems to visit a doctor or hospital by building an Android-based application that is able to estimate a person's illness. This application works through a classification approach by processing data on symptoms experienced by patients using the Naïve Bayes method. The test results using data testing show this application can estimate diseases with accuracy up to 100\% for four or more symptom testing data.
\end{abstract}

Keywords - classification; disease; application; Android; Naïve Bayes

ABSTRAK - Menderita sakit merupakan hal biasa dalam kehidupan manusia. Saat menderita sakit, seseorang biasanya pergi memeriksakan dirinya ke dokter untuk memperoleh informasi mengenai penyakitnya. Namun, karena beberapa alasan seperti biaya, waktu, jarak, atau lainnya banyak orang yang tengah menderita sakit tidak bisa memeriksakan diri ke dokter. Penelitian ini merupakan sebuah upaya untuk memberikan alternatif bagi masyarakat yang memiliki kendala untuk mendatangi dokter atau rumah sakit dengan membangun sebuah aplikasi berbasis Android yang mampu memperkirakan penyakit seseorang. Aplikasi ini bekerja melalui pendekatan klasifikasi dengan mengolah data gejala-gejala yang dialami penderita menggunakan metode Nä̈ve Bayes. Hasil pengujian menggunakan data uji menunjukkan aplikasi ini dapat memperkirakan penyakit dengan keakuratan hingga $100 \%$ untuk empat data gejala atau lebih.

Kata Kunci - klasifikasi; penyakit; aplikasi; Android; Nä̈ve Bayes

\section{Pendahuluan}

Kesehatan merupakan hal yang sangat penting bagi setiap manusia. Disamping merupakan kenikmatan yang bisa dirasakan secara langsung, kesehatan juga memungkinkan manusia melakukan berbagai aktifitas dikehendakinya. Karena itu, manusia secara alamiah akan berusaha menjaga tubuhnya tetap sehat. Meski demikian, tidak setiap saat manusia dikaruniakan kesehatan. Ada kalanya manusia mengalami sakit, mulai dari sakit yang ringan seperti flu atau pusing, hingga sakit yang berat yang dapat berujung pada kematian, seperti penyakit jantung atau kanker.

Ketika seseorang menderita sakit, biasanya dia akan berusaha mengenali sendiri apa penyakit yang dideritanya itu $[3,4]$. Bagi sebagian orang, kesehatan bukan masalah yang besar yang selalu membutuhkan bantuan dokter, asal mereka tahu cara menghadapinya [1]. Tapi, banyak orang tidak begitu paham mengenai seluk beluk kesehatan, sehingga bila sakit ia perlu memeriksakan diri ke dokter atau rumah sakit untuk memperoleh pengobatan. Meski demikian, tidak selalu seseorang yang menderita sakit tersebut dapat pergi memeriksakan dirinya ke dokter atau rumah sakit karena berbagai alasan atau kendala. Misalnya, karena tempat berobat tersebut jauh dari tempat tinggalnya, tidak ada yang mengantar, atau tidak mempunyai cukup uang untuk menebus biaya berobat, dan lain sebagainya. Selain itu, sebagian orang ada yang merasa kuatir atau takut berobat, 
misalnya karena tidak ingin disuntik, dan alasanalasan psikologis lainnya. Hal semacam ini tentu tidak baik bagi penderita, karena bisa jadi penyakit yang bersangkutan akan semakin parah, bahkan bisa berakibat kematian. Selain itu, ada beberapa penyakit yang dapat menular, sehingga apabila penyakit tersebut tidak segera ditangani, maka penyakit itu dapat menyebar kepada orang di sekitarnya.

Kendala tersebut di atas sebenarnya dapat dicarikan jalan keluarnya, yaitu dengan memanfaatkan teknologi informasi yang saat ini sudah sangat berkembang. Salah satunya adalah dengan membangun suatu aplikasi pengenalan penyakit menggunakan media telepon pintar (smartphone) dengan sistem operasi Android. Saat ini telepon pintar merupakan alat komunikasi yang sudah tidak asing lagi karena sudah dimanfaatkan secara luas di dalam kehidupan masyarakat Indonesia [10]. Apalagi harga perangkat ini juga terus mengalami penurunan, sehingga dapat menjangkau seluruh kalangan.

Pada prinsipnya, cara kerja aplikasi yang dibuat dalam penelitian ini cukup sederhana, mirip seperti cara dokter mengidentifikasi sebuah penyakit. Kuncinya terletak pada analisis terhadap gejalagejala penyakit. Berdasarkan pengalaman dan pengetahuannya, seorang dokter biasanya mengaitkan gejala-gejala yang ditunjukkan oleh tubuh penderita dengan kemungkinan penyakit. Sistem ini juga menggunakan pendekatan yang mirip, di mana pada sistem akan dimasukkan (input) sejumlah gejala penyakit, kemudian sistem akan melakukan analisis kemungkinan penyakit yang paling mungkin berdasarkan data yang tersimpan di dalam databasenya.

Penelitian ini menggunakan metode Naïve Bayes untuk menganalisis gejala-gejala yang dirasakan atau yang tampak pada penderita untuk memperkirakan kemungkinan penyakit yang diderita. Dalam hal ini algoritma Naïve Bayes bekerja dengan cara menghitung peluang (probabilitas) keterkaitan penyakit dengan gejala-gejala yang diberikan sehingga akan dihasilkan luaran berupa beberapa kemungkinan penyakit dengan peluang tertinggi. Algoritma Naïve Bayes ini ditanam ke dalam perangkat telepon pintar (smartphone) berbasis sistem operasi Android.

Dengan sistem ini seorang penderita penyakit dapat memperkirakan kemungkinan penyakit yang dideritanya, seakan-akan dia tengah memeriksakan dirinya kepada seorang dokter yang ahli. Meskipun untuk pemeriksaan yang lebih lengkap dan teliti masih diperlukan keahlian seorang dokter, setidaknya sistem ini dapat digunakan sebagai suatu acuan awal untuk memperkirakan penyakit yang diderita oleh seseorang.

\section{METODE DAN BAHAN}

\subsection{Klasifikasi Bayes}

Klasifikasi atau pengelompokkan adalah proses yang amat lazim saat mengelola sekumpulan data. Dalam konteks Data Mining, klasifikasi adalah proses memetakan himpunan atribut (attribute set) kepada kelas-kelas target tertentu (predefined class). Secara simbolik, himpunan atribut dilambangkan dengan $x$, sedangkan kelas-kelas target disebut dengan $y$ [9]. Dengan kata lain, tujuan klasifikasi adalah untuk memperkirakan atau memprediksi kelas suatu objek yang labelnya belum atau tidak diketahui. Adapun hasil akhir klasifikasi adalah terbentuknya suatu model yang dapat mengelompokkan sekumpulan data atribut (attribute set) ke dalam kelas-kelas yang berbeda-beda (variable class) menurut aturan atau fungsi tertentu.

Dalam beragam penerapan, hubungan antara attribute set dengan variable class tidaklah pasti. Itu berarti, class lable sebuah pelatihan data tidak bisa atau belum dapat ditentukan secara pasti meskipun attribute set-nya persis sama. Keadaan ini boleh jadi ditimbul akibat adanya derau (noise), atau juga karena adanya faktor luar yang tidak diketahui yang turut mempengaruhi proses pengelompokan itu.

Salah satu metode klasifikasi yang banyak digunakan saat ini adalah klasifikasi Naïve Bayes atau singkatnya klasifikasi Bayesian. Metode ini diantaranya digunakan untuk keperluan klasifikasi nasabah bank [2] dan penyakit mata [8]. Klasifikasi Bayesian merupakan metode klasifikasi yang memodelkan hubungan probabilistik antara attribute set dengan variable class. Karena itu, hubungan attribute set dengan variable class tidak pasti (deterministic), namun lebih bersifat kemungkinan atau peluang.

Misalkan, diketahui variabel acak X dan Y. Maka, hubungan kemungkinan variabel $X$ bernilai $x$ dan variabel $Y$ bernilai $y$ dapat dinyatakan sebagai $P(X=$ $\mathrm{x}, \mathrm{Y}=\mathrm{y})$. Adapun probabilitas bersyaratnya adalah kemungkinan variabel acak bernilai tertentu terhadap variabel acak yang lainnya yang sudah diketahui. Misalnya, probabilitas bersyarat $\mathrm{P}(\mathrm{Y}=\mathrm{y} \mid \mathrm{X}=\mathrm{x})$ adalah probabilitas variabel $\mathrm{Y}$ akan bernilai $y$, untuk variabel $X$ yang sudah diketahui bernilai $x$. Hubungan probabilitas bersyarat $X$ dan $Y$ dapat dinyatakan sebagai:

$$
\begin{aligned}
& P(X, Y)=P(Y \mid X) \times P(X) \\
= & P(X \mid Y) \times P(Y) \ldots \ldots .(1)
\end{aligned}
$$


Dari persamaan (1), X menunjukan attribute set dan Y menunjukan variable class. Jika variable class memiliki hubungan yang tidak pasti dengan atributnya, maka $X$ dan $Y$ dapat dipandang sebagai variabel acak dan hubungan probabilitas keduanya dapat dituliskan sebagai $\mathrm{P}(\mathrm{Y} \mid \mathrm{X})$. Probabilitas bersyarat ini diketahui sebagai probabilitas posterior untuk Y, dan sebagai lawannya probabilitas prior $\mathrm{P}(\mathrm{Y})$.

Klasifikasi Naïve Bayes menghitung probabilitas kelas bersyarat dengan asumsi bahwa atribut tersebut bersifat bebas secara bersyarat, diberi label kelas y. Asumsi kebebasan bersyarat bisa dinyatakan dalam persamaan berikut:

$$
P(X \mid Y=y)=\prod_{i=1}^{d} P\left(X_{i} \mid Y=y\right) \ldots
$$

Dimana setiap attribute set $\mathrm{X}=\left\{\mathrm{X}_{1}, \mathrm{X}_{2}, \ldots, \mathrm{X}_{\mathrm{d}}\right\}$ sebanyak $d$ atribut.

\subsection{Perancangan Sistem}

Aplikasi yang diberi nama D-KIT ini akan dibuat dalam sistem berbasi Android. Android merupakan sistem operasi yang dikembangkan oleh Google dan merupakan modifikasi dari kernel Linux serta dikembangkan khusus untuk perangkat berbasis layar sentuh (touch screen) [5]. Secara umum, Android saat ini menjadi sistem operasi yang paling banyak digunakan pada gawai telpon pintar atau komputer tablet, termasuk di Indonesia [10]

Aplikasi ini dirancang sebagai sebuah aplikasi yang dapat dipakai oleh siapapun dengan tanpa ada pembatasan. Dengan kata lain, tidak diperlukan proses login untuk bisa dapat menggunakannya. Semua pengguna (user) dapat mengakses setiap fungsi-fungsi yang ada di dalam sistem. Adapun cara kerjanya akan ditunjukkan oleh beberapa

\section{Gambar 1.}

\section{Use Case Diagram}

Use case diagram adalah diagram yang menggambarkan interaksi antara elemen-elemen yang ada di dalam sistem [9].

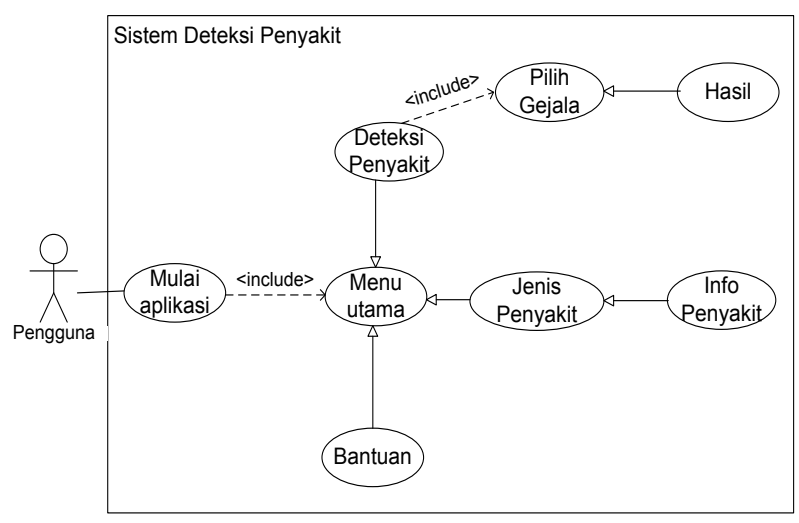

Gambar 1. Use Case Diagram

Gambar 1 menggambarkan interaksi antara pengguna (actor) dengan sistem. Pengguna di sini hanya ada satu, yaitu setiap orang yang menggunakan aplikasi ini. Terdapat delapan buah use case yang dapat diakses oleh pengguna (actor), yaitu Mulai Aplikasi, Menu Utama, Deteksi Penyakit, Pilih Gejala, Hasil, Jenis Penyakit Info Penyakit, dan Bantuan. Deskripsi lebih lengkap dari masingmasing use case tersebut dapat dilihat pada tabel 1.

Tabel 1. Deskripsi Use Case

\begin{tabular}{|c|c|c|}
\hline No & Use Case & Deskripsi \\
\hline 1 & $\begin{array}{l}\text { Mulai } \\
\text { aplikasi }\end{array}$ & Pengguna memulai aplikasi \\
\hline 2 & Menu utama & $\begin{array}{l}\text { Pengguna melihat tampilan } \\
\text { menu utama }\end{array}$ \\
\hline 3 & $\begin{array}{l}\text { Deteksi } \\
\text { Penyakit }\end{array}$ & $\begin{array}{l}\text { Pengguna mengaktifkan } \\
\text { aplikasi pengenalan penyakit }\end{array}$ \\
\hline 4 & Pilih gejala & $\begin{array}{l}\text { Pengguna menginput } \\
\text { sejumlah gejala sakit. }\end{array}$ \\
\hline 5 & Hasil & $\begin{array}{l}\text { Pengguna melihat hasil } \\
\text { perhitungan probabilitas } \\
\text { terbesar }\end{array}$ \\
\hline 6 & $\begin{array}{l}\text { Jenis } \\
\text { Penyakit }\end{array}$ & $\begin{array}{l}\text { Pengguna mencari informasi } \\
\text { jenis penyakit }\end{array}$ \\
\hline 7 & Info penyakit & $\begin{array}{l}\text { Pengguna menampilkan } \\
\text { informasi dari jenis penyakit } \\
\text { yang dipilih user }\end{array}$ \\
\hline 8 & Bantuan & $\begin{array}{l}\text { Pengguna melihat cara } \\
\text { penggunaan aplikasi }\end{array}$ \\
\hline
\end{tabular}

\section{Sequence Diagram}

Setelah didefinisikan, diagram use case kemudian dijabarkan ke dalam sequence diagram. Sequence diagram adalah gambaran mengenai uruturutan peristiwa (sequence of event) yang menunjukkan bagaimana objek-objek dalam sistem atau kelas saling berinteraksi satu dengan lainnya. 
Beberapa sequence diagram, seperti Memulai Aplikasi, Deteksi Penyakit, Jenis Penyakit, dan Informasi Aplikasi masing-masing ditunjukkan oleh Gambar 2, 3, 4, dan 5 .

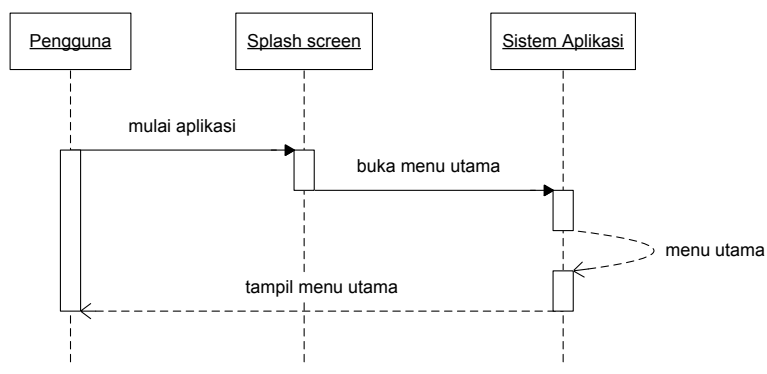

Gambar 2. Sequence diagram untuk Memulai Aplikasi

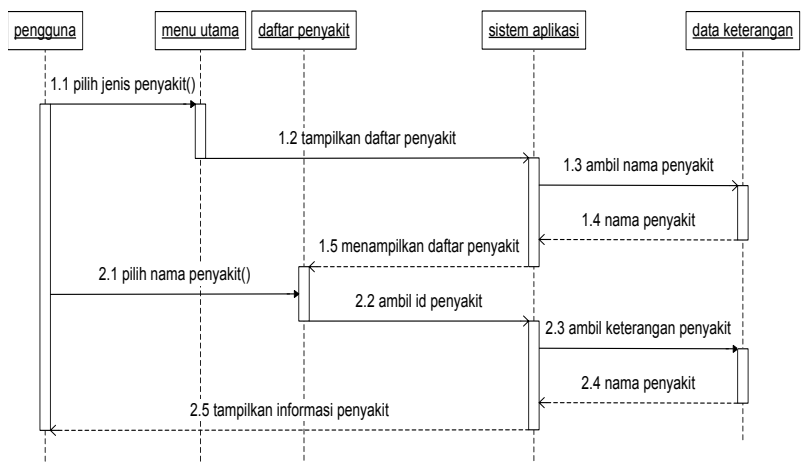

Gambar 3. Sequence Diagram untuk Menu Deteksi Penyakit

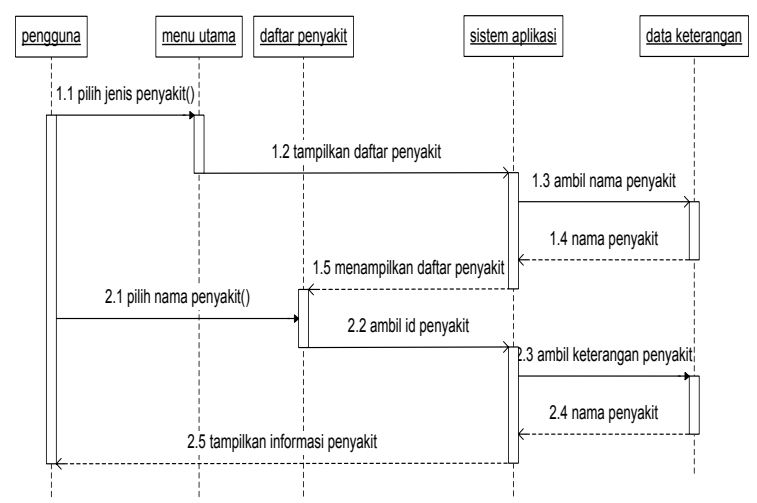

Gambar 4. Sequence Diagram untuk Menu Jenis Penyakit.

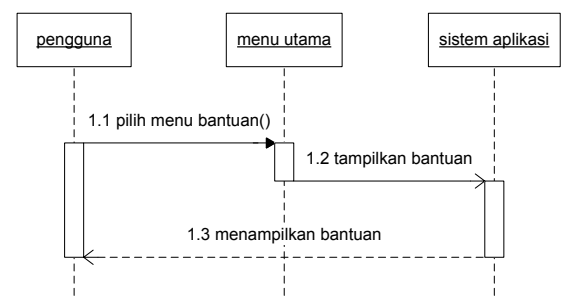

Gambar 5. Sequence Diagram untuk Menu Informasi Aplikasi.

\subsection{Perancangan Data}

Data yang akan diolah dalam aplikasi ini merupakan data berbagai jenis penyakit beserta gejala-gejala sakit yang terkait dengan penyakit tersebut. Ada tiga kelompok field yang termasuk dalam data gejala, yaitu id, penyakit, dan gejala. Field id menunjukkan nomor urut penyakit, sedangkan field penyakit dan gejala berisikan masing-masing data nama penyakit dan gejalanya.

Data penyakit dan gejala-gejalanya itu merupakan data asli yang diperoleh dari salah satu rumah sakit di Bandung. Terdapat 80 gejala penyakit yang berkaitan dengan 36 jenis penyakit. Dengan demikian, kemampuan aplikasi mengenali jenis penyakit terbatas pada ke-36 jenis penyakit tersebut.

Setiap penyakit memiliki beberapa gejala, yaitu antara 4-10 gejala. Misalnya, sakit asam urat (25) memiliki gejala nyeri sendi (27), pembengkakan sendi (28), kesemutan (32), dan sakit sendi ketika bergerak (34). Namun demikian, gejala itu tidak bersifat ekslusif, artinya, gejala yang ada pada suatu penyakit mungkin juga terdapat pada penyakit lain. Misalnya, gejala demam dapat ditemukan pada beberapa penyakit seperti demam berdarah, tifus, rubella, TBC, sinusitis, dan beberapa penyakit lainnya.

Data ini disimpan di dalam database aplikasi yang tersimpan pada memori telepon pintar yang digunakan untuk meng-install aplikasi ini. Data gejala-gejala sakit inilah yang akan digunakan dalam perhitungan statistik Bayesian untuk memperkirakan jenis penyakit yang diderita seseorang. Adapun daftar gejala penyakit tersebut dapat dilihat pada Tabel 2, sedangkan data penyakit berikut gejalanya dapat dilihat pada Tabel 3 .

Tabel 2. Daftar gejala penyakit

\begin{tabular}{clll}
\hline No & \multicolumn{1}{c}{ Gejala } & No & \multicolumn{1}{c}{ Gejala } \\
\hline 1 & Tidak enak badan & 41 & Gatal-gatal \\
\hline 2 & Demam & 42 & Bercak pada kulit \\
\hline 3 & Panas dingin & 43 & Mudah memar \\
\hline 4 & Gemetaran/ Menggigil & 44 & Memar tanpa sebab \\
\hline 5 & Sakit kepala & 45 & Kulit menjadi kuning \\
\hline 6 & Pusing & 46 & Muka memerah \\
\hline 7 & Gatal pada mata & 47 & Mual \\
\hline 8 & Pandangan kabur & 48 & Perut tidak enak \\
\hline 9 & Nyeri lidah & 49 & Kembung \\
\hline 10 & Sariawan & 50 & Sering bersendawa \\
\hline 11 & Gatal di tenggorokan & 51 & Nyeri perut \\
\hline 12 & Sakit saat menelan & 52 & Nyeri perut sebelah \\
& & & kanan \\
\hline 13 & Sakit Tenggorokan & 53 & Kram pada perut \\
\hline
\end{tabular}


W Zarman \& D Yuliawardhani

Komputika, Vol. 7, No. 1, April 2018

\begin{tabular}{|c|c|c|c|}
\hline 14 & Amandel membengkak & 54 & Diare \\
\hline 15 & Suara serak & 55 & Susah buang air besar \\
\hline 16 & Batuk & 56 & Tinja berdarah \\
\hline 17 & Batuk saat kedinginan & 57 & Tinja berlendir \\
\hline 18 & Batuk kering & 58 & Muntah-muntah \\
\hline 19 & Batuk berdahak & 59 & Sering berkemih \\
\hline 20 & Hidung tersumbat & 60 & $\begin{array}{l}\text { Kehilangan nafsu } \\
\text { makan }\end{array}$ \\
\hline 21 & Mimisan & 61 & Perut merasa lapar \\
\hline 22 & Bersin-bersin & 62 & $\begin{array}{l}\text { Nafsu makan } \\
\text { bertambah }\end{array}$ \\
\hline 23 & Mengi & 63 & Tubuh lemas \\
\hline 24 & Nyeri pada telinga & 64 & Mudah lelah \\
\hline 25 & Nyeri pada Sinus & 65 & Dehidrasi \\
\hline 26 & Nyeri tulang & 66 & Berat badan turun \\
\hline 27 & Nyeri sendi & 67 & Kurang berkeringat \\
\hline 28 & Pembengkakan sendi & 68 & Keringat berlebihan \\
\hline 29 & $\begin{array}{l}\text { Pembengkakan } \\
\text { kelenjar getah bening }\end{array}$ & 69 & Berkeringat dingin \\
\hline 30 & $\begin{array}{l}\text { Pembengkakan } \\
\text { kelenjar getah bening } \\
\text { di leher }\end{array}$ & 70 & Kejang-kejang \\
\hline 31 & Nyeri otot & 71 & Kaku pada otot \\
\hline & Kesemutan & 72 & Detak jantung cepat \\
\hline 33 & Hilang keseimbangan & 73 & Denyut nadi melemah \\
\hline 34 & $\begin{array}{l}\text { Sakit sendi saat } \\
\text { bergerak }\end{array}$ & 74 & $\begin{array}{l}\text { Detak jantung tidak } \\
\text { teratur }\end{array}$ \\
\hline & $\begin{array}{l}\text { Sendi kaku setelah } \\
\text { diam lama }\end{array}$ & 75 & Pucat \\
\hline 36 & Hilang kesadaran & 76 & Sesak nafas \\
\hline 37 & Gangguan konsentrasi & 77 & Nafas menjadi cepat \\
\hline & Linglung & 78 & Sakit saat bernafas \\
\hline & Mengigau & 79 & Sakit pada dada \\
\hline & Gelisah & 80 & Dada terasa sempit \\
\hline
\end{tabular}

\begin{tabular}{|c|c|c|}
\hline 10 & Influenza & $1,2,3,5,13,16,20,22,31,64$ \\
\hline 11 & Asma & $17,23,76,80$ \\
\hline 12 & Pneumonia & $\begin{array}{l}2,5,16,27,47,58,60,68,72,76,77,7 \\
9\end{array}$ \\
\hline 13 & Bronchitis & $5,8,13,19,20,23,46,64,76,79$ \\
\hline 14 & ISPA & $2,4,16,36,64,76$ \\
\hline 15 & Hipotensi & $6,8,33,36,47,63,74$ \\
\hline 16 & Maag & $47,49,51,58,60,61$ \\
\hline 17 & Disentri & $47,51,53,54,56,56,63,65,75$ \\
\hline 18 & Gastroenteritis & $2,4,5,47,51,53,54,58,65,66$ \\
\hline 19 & Diabetes Melitus & $6,8,47,59,62,64,65,66$ \\
\hline 20 & $\begin{array}{l}\text { Keracunan } \\
\text { Makanan }\end{array}$ & $47,51,53,54,58$ \\
\hline 21 & Alergi & $7,16,20,22,42,76$ \\
\hline 22 & $\begin{array}{l}\text { Radang } \\
\text { Tenggorokan }\end{array}$ & $2,12,13,14,15,30$ \\
\hline 23 & Laringitis & $2,13,15,18,20,30$ \\
\hline 24 & Tonsilitis & $1,2,3,5,7,12,13,14,16,24,30$ \\
\hline 25 & Asam Urat & $27,28,32,34$ \\
\hline 26 & Gout & $1,2,4,27,28,34,35$ \\
\hline 27 & Kolitis & $2,4,49,51,54,56,63,65$ \\
\hline 28 & $\begin{array}{l}\text { Radang Usus } \\
\text { Buntu }\end{array}$ & $2,47,49,52,58,60$ \\
\hline 29 & Amebiasis & $2,49,53.54 .56$ \\
\hline 30 & Heatstroke & $\begin{array}{l}2,5,36,39,46,47,58,67,70,71,72,7 \\
7\end{array}$ \\
\hline 31 & Hipertensi & $5,8,40,46,47,58,63,76$ \\
\hline 32 & Stroke & $5,6,8,32,33,38,63$ \\
\hline & Syok & $6,36,47,68,69,72,73,75,77,79$ \\
\hline 34 & Anemia & $6,37,60,63,66,68,75$ \\
\hline 35 & Serangan jantung & $6,47,58,63,69,72,76,79$ \\
\hline 36 & Jantung Koroner & $6,47,72,74,76,79$ \\
\hline
\end{tabular}

\section{HASIL DAN PEMBAHASAN}

Tabel 3. Daftar penyakit berikut gejalanya masing-masing

\begin{tabular}{cll}
\hline No & Nama penyakit & \multicolumn{1}{c}{ Nomor Urut Gejala } \\
\hline 1 & Demam Berdarah & $\begin{array}{l}2,5,6,7,27,31,42,47,51,58,60,63, \\
69\end{array}$ \\
\hline 2 & Rubella & $2,5,7,20,27,29,42,60$ \\
\hline 3 & Malaria & $2,5,31,47,58,60,63,68,75$ \\
\hline 4 & Sirosis & $37,38,41,43,45,47,58,60,63,64$ \\
\hline 5 & Hepatitis A & $6,13,27,31,4547,54,60,64$ \\
\hline 6 & Tifus & $2,4,5,31,51,55,60,63,73$ \\
\hline 7 & Kolera & $47,51,53,5458,63,65,72$ \\
\hline 8 & TBC & $2,19,63,66,69,72,76,79$ \\
\hline 9 & Sinusitis & $2,5,9,16,20,25$ \\
\hline & &
\end{tabular}

Setelah aplikasi dibuat, dilakukan pengujian alpha dan beta untuk mengukur keandalan aplikasi yang telah dibuat. Dalam hal ini, ada dua pengujian yang dilakukan, yaitu pengujian alpha dan pengujian data.

\subsection{Pengujian Alpha}

Pengujian alpha dilakukan dengan menggunakan metode black box testing. Black box testing adalah pengujian terhadap fungsi-fungsi dalam aplikasi untuk mengetahui apakah sudah sesuai dengan skenario uji yang telah dipersiapkan [6]. Jika hasil pengujian sesuai dengan hasil yang diharapkan, berarti kesimpulannya berhasil, dan 
bila sebaliknya berarti gagal. Hasil pengujian alpha dapat dilihat pada Tabel 4.

Tabel 4. Hasil Pengujian Alpha

\begin{tabular}{|c|c|c|c|}
\hline \multirow{2}{*}{$\begin{array}{c}\text { Kasus } \\
\text { yang diuji }\end{array}$} & \multicolumn{3}{|c|}{ Skenario dan Hasil Uji } \\
\hline & Skenario Uji & $\begin{array}{l}\text { Hasil yang } \\
\text { Diharapkan }\end{array}$ & $\begin{array}{l}\text { Kesim- } \\
\text { pulan }\end{array}$ \\
\hline $\begin{array}{l}\text { Splash } \\
\text { screen }\end{array}$ & $\begin{array}{l}\text { Menampilka } \\
\text { n menu } \\
\text { utama }\end{array}$ & $\begin{array}{l}\text { Aplikasi dapat } \\
\text { memulai } \\
\text { program dan } \\
\text { menampilkan } \\
\text { menu utama. }\end{array}$ & Berhasil \\
\hline $\begin{array}{l}\text { Deteksi } \\
\text { Button }\end{array}$ & $\begin{array}{l}\text { Pilih menu } \\
\text { Deteksi } \\
\text { penyakit }\end{array}$ & $\begin{array}{l}\text { Menampilkan } \\
\text { daftar gejala } \\
\text { dalam beberapa }\end{array}$ & Berhasil \\
\hline \multirow[t]{2}{*}{$\begin{array}{l}\text { Ekspand } \\
\text { list }\end{array}$} & \multirow[t]{2}{*}{ Pilih kategori } & $\begin{array}{l}\text { Memperlihatkan } \\
\text { daftar gejala pada } \\
\text { kategori tersebut }\end{array}$ & Berhasil \\
\hline & & $\begin{array}{l}\text { Menutup daftar } \\
\text { gejala pada pada } \\
\text { kategori tersebut }\end{array}$ & Berhasil \\
\hline Spinner & Pilih spinner & $\begin{array}{l}\text { Menampilkan } \\
\text { penjelasan gejala }\end{array}$ & $\begin{array}{l}\text { Tidak } \\
\text { berhasil }\end{array}$ \\
\hline \multirow[t]{2}{*}{ Check box } & \multirow{2}{*}{$\begin{array}{l}\text { Pilih Check } \\
\text { box }\end{array}$} & Check box terisi & Berhasil \\
\hline & & $\begin{array}{l}\text { Check box } \\
\text { terhapus }\end{array}$ & Berhasil \\
\hline $\begin{array}{l}\text { Hitung } \\
\text { Button }\end{array}$ & $\begin{array}{l}\text { Menampilka } \\
\mathrm{n} \text { hasil }\end{array}$ & $\begin{array}{l}\text { Mengambil } \\
\text { masukan, proses } \\
\text { klasifikasi, lalu } \\
\text { memampilkan } \\
\text { hasil }\end{array}$ & Berhasil \\
\hline Info Button & $\begin{array}{l}\text { Menampilka } \\
\mathrm{n} \text { daftar } \\
\text { penyakit }\end{array}$ & $\begin{array}{l}\text { Program akan } \\
\text { mengambil dan } \\
\text { menampilkan } \\
\text { daftar penyakit } \\
\text { dari database }\end{array}$ & Berhasil \\
\hline $\begin{array}{l}\text { Pilih } \\
\text { Penyakit }\end{array}$ & $\begin{array}{l}\text { Pilih nama } \\
\text { penyakit }\end{array}$ & $\begin{array}{l}\text { Program akan } \\
\text { mengambil data } \\
\text { informasi } \\
\text { penyakit yang } \\
\text { sudah dipilih } \\
\text { dari database dan } \\
\text { menampilkannya }\end{array}$ & Berhasil \\
\hline Info Button & $\begin{array}{l}\text { Pilih menu } \\
\text { Bantuan }\end{array}$ & $\begin{array}{l}\text { Menampilkan } \\
\text { cara } \\
\text { menggunakan } \\
\text { aplikasi }\end{array}$ & Berhasil \\
\hline
\end{tabular}

\subsection{Pengujian Data}

Pengujian data adalah pengujian untuk mengukur keberhasilan aplikasi dalam memprediksi penyakit berdasarkan data gejala yang diinputkan. Hal ini untuk mengetahui seberapa akurat penggunaan metode Bayesian ini. Dalam hal ini data yang digunakan adalah 20 set data penyakit baru, artinya data yang berbeda dengan data yang tersimpan di database (lihat Tabel 5).
Tabel 5. Data pengujian

\begin{tabular}{|c|c|c|c|}
\hline No. & Nama Penyakit & No. & Nama Penyakit \\
\hline 1 & Influenza & 11 & Tifus \\
\hline 2 & Demam Berdarah & 12 & Bronchitis \\
\hline 3 & Maag & 13 & Gastroenteritis \\
\hline 4 & Rubella & 14 & Hipotensi \\
\hline 5 & Disentri & 15 & $\mathrm{TBC}$ \\
\hline 6 & Keracunan Makanan & 16 & Radang Usus Buntu \\
\hline 7 & Hepatits A & 17 & Stroke \\
\hline 8 & Amebiasis & 18 & Syok \\
\hline 9 & Asma & 19 & Anemia \\
\hline 10 & Radang Tenggorokan & 20 & Serangan Jantung \\
\hline
\end{tabular}

Pengujian ini dilakukan dengan cara memberikan masukan berupa data gejala penyakit, kemudian mengecek apakah aplikasi dapat memberikan kesimpulan penyakit yang sesuai atau tidak. Dalam hal ini ada empat skenario yang dilakukan, di mana skenario ini menunjukkan banyaknya data masukan (gejala penyakit) yang digunakan, yaitu

a. skenario lima masukan

b. skenario empat masukan

c. skenario tiga masukan

d. skenario dua masukan

Bila jumlah masukan yang dibutuhkan lebih sedikit daripada masukan yang ada, maka masukan dipilih secara acak. Misalnya, dalam skenario empat masukan penyakit Asma memiliki tujuh gejala, maka dipilih empat dari tujuh gejala sebagai masukan sesuai dengan skenarionya.

Kesimpulan dari pengujian ini ada tiga, yaitu

a. VL (valid), yaitu bila luaran aplikasi menunjukan penyakit yang sesuai dengan acuan pada urutan pertama.

b. ID (indikasi lain), yaitu bila luaran aplikasi menunjukan penyakit yang sesuai dengan acuan pada urutan kedua atau ketiga.

c. TV (tidak valid) jika luaran aplikasi menunjukan tidak ada penyakit yang sesuai dengan acuan.

Untuk contoh hasil pengujian skenario c (tiga masukan) dapat dilihat pada tabel 6. Dari tabel itu diperoleh dari 20 set data uji diperoleh 17 data valid (VL), 2 tidak valid (TV), dan satu indikasi lain (ID). Itu artinya, ketepatan memprediksi sistem dalam skenario ini mencapai 85\% (17/20). 
W Zarman \& D Yuliawardhani

Komputika, Vol. 7, No. 1, April 2018

Tabel 6. Hasil Pengujian skenario c (tiga masukan)

\begin{tabular}{|c|c|c|c|}
\hline \multirow[b]{2}{*}{ No } & \multicolumn{3}{|c|}{ Tiga gejala } \\
\hline & Gejala & Luaran & $\begin{array}{c}\text { Kesim } \\
\text { pulan }\end{array}$ \\
\hline 1 & $2,5,13$ & $\begin{array}{l}\text { Influenza } \\
\text { Radang } \\
\text { tenggorokan } \\
\text { Laringitis }\end{array}$ & VL \\
\hline 2 & $2,42,51$ & $\begin{array}{l}\text { Demam berdarah } \\
\text { Kolitis } \\
\text { Rubella }\end{array}$ & VL \\
\hline 3 & $\begin{array}{l}47,49 \\
51\end{array}$ & $\begin{array}{l}\text { Maag } \\
\text { Kolitis } \\
\text { Radang usus } \\
\text { buntu }\end{array}$ & VL \\
\hline 4 & $5,27,42$ & $\begin{array}{l}\text { Rubella } \\
\text { Pneumonia } \\
\text { Stroke }\end{array}$ & VL \\
\hline 5 & $\begin{array}{l}47,51, \\
58\end{array}$ & $\begin{array}{l}\text { Keracunan } \\
\text { makanan } \\
\text { Disentri } \\
\text { Heatstroke }\end{array}$ & ID \\
\hline 6 & $\begin{array}{l}47,51, \\
54\end{array}$ & $\begin{array}{l}\text { Keracunan } \\
\text { makanan } \\
\text { Gastroenteritis } \\
\text { Kolitis }\end{array}$ & VL \\
\hline 7 & $6,31,60$ & $\begin{array}{l}\text { Hepatitis A } \\
\text { Anemia } \\
\text { Serangan jantung }\end{array}$ & VL \\
\hline 8 & $2,49,53$ & $\begin{array}{l}\text { Amebiasis } \\
\text { Heatstroke } \\
\text { Kolitis }\end{array}$ & VL \\
\hline 9 & $\begin{array}{l}17,23 \\
76\end{array}$ & $\begin{array}{l}\text { Asma } \\
\text { Bronchitis } \\
\text { Serangan jantung }\end{array}$ & VL \\
\hline 10 & $\begin{array}{l}12,13 \\
14\end{array}$ & $\begin{array}{l}\text { Radang } \\
\text { Tenggorokan } \\
\text { Laringitis } \\
\text { Serangan jantug }\end{array}$ & VL \\
\hline 11 & $2,5,55$ & $\begin{array}{l}\text { Tifus } \\
\text { Heatstroke } \\
\text { Influenza }\end{array}$ & VL \\
\hline 12 & $5,13,19$ & $\begin{array}{l}\text { Bronchitis } \\
\text { Influenza } \\
\text { Stroke }\end{array}$ & VL \\
\hline 13 & $2,54,63$ & $\begin{array}{l}\text { Kolitis } \\
\text { Amebiasis } \\
\text { Heatstroke }\end{array}$ & TV \\
\hline 14 & $6,63,74$ & $\begin{array}{l}\text { Hipotensi } \\
\text { Jantung koroner } \\
\text { Anemia }\end{array}$ & VL \\
\hline 15 & $2,19,63$ & $\begin{array}{l}\text { TBC } \\
\text { Kolitis } \\
\text { Malaria }\end{array}$ & VL \\
\hline 16 & $2,47,51$ & $\begin{array}{l}\text { Gastroenteritis } \\
\text { Kolitis }\end{array}$ & TV \\
\hline
\end{tabular}

\begin{tabular}{|c|c|c|c|}
\hline & & Disentri & \\
\hline 17 & $5,6,32$ & $\begin{array}{l}\text { Stroke } \\
\text { Demam berdarah } \\
\text { Serangan jantung }\end{array}$ & VL \\
\hline 18 & $\begin{array}{l}69,72 \\
75\end{array}$ & $\begin{array}{l}\text { Syok } \\
\text { Serangan jantung } \\
\text { Anemia }\end{array}$ & VL \\
\hline 19 & $6,37,63$ & $\begin{array}{l}\text { Anemia } \\
\text { Sirosis } \\
\text { Serangan jantung }\end{array}$ & VL \\
\hline 20 & $6,63,72$ & $\begin{array}{l}\text { Serangan Jantung } \\
\text { Jantung koroner } \\
\text { TBC }\end{array}$ & VL \\
\hline
\end{tabular}

Hasil pengujian keempat skenario dapat dilihat pada tabel 7 dan 8. Terlihat dari kedua tabel ini bahwa akurasi skenario satu dan dua lebih baik dibandingkan skenario tiga dan empat.

Tabel 7. Rekapitulasi skenario satu (lima masukan) dan dua (empat masukan)

\begin{tabular}{lcccc}
\hline Hasil & \multicolumn{2}{c}{ Masukan lima data } & \multicolumn{2}{c}{ Masukan empat data } \\
Jumlah & $\begin{array}{c}\text { Persentase } \\
\text { kasus }\end{array}$ & $\begin{array}{c}\text { Jumlah } \\
\text { kasus }\end{array}$ & $\begin{array}{c}\text { Persentase } \\
(\mathbf{\%})\end{array}$ \\
\hline VL & 20 & 100 & 19 & 95 \\
ID & - & - & 1 & 5 \\
TV & - & - & - & - \\
Jumlah & $\mathbf{2 0}$ & $\mathbf{1 0 0}$ & $\mathbf{2 0}$ & $\mathbf{1 0 0}$ \\
\hline
\end{tabular}

Tabel 8. Rekapitulasi skenario tiga (tiga masukan) dan empat (dua masukan)

\begin{tabular}{lcccc}
\hline Hasil & \multicolumn{2}{c}{ Masukan tiga data } & \multicolumn{2}{c}{ Masukan dua data } \\
& Jumlah & $\begin{array}{c}\text { Persentase } \\
\text { k\%) }\end{array}$ & $\begin{array}{c}\text { Jumlah } \\
\text { kasus }\end{array}$ & $\begin{array}{c}\text { Persentase } \\
(\mathbf{\%})\end{array}$ \\
\hline VL & 17 & 85 & 9 & 45 \\
ID & 1 & 5 & 2 & 10 \\
TV & 2 & 10 & 9 & 45 \\
Jumlah & $\mathbf{2 0}$ & $\mathbf{1 0 0}$ & $\mathbf{2 0}$ & $\mathbf{1 0 0}$ \\
\hline
\end{tabular}

\subsection{Analisis}

Berdasarkan pengujian alpha (black box testing), diperoleh hasil bahwa semua fungsi-fungsi aplikasi berhasil dijalankan. Artinya, secara fungsional aplikasi ini sudah berjalan sebagaimana yang direncanakan (lihat Tabel 4).

Sementara itu, dari segi pengujian data dapat disimpulkan bahwa jumlah data masukan mempengaruhi akurasi aplikasi dalam memprediksi penyakit. Tabel 7 dan 8 menunjukkan akurasi prediksi yang mendekati sempurna (100\% dan 95\%) bila masukan terdiri dari lima atau empat masukan. Oleh karena itu, dapat dikatakan bahwa lima atau empat masukan merupakan jumlah masukan yang optimal. Sementara jika masukan hanya tiga gejala 
saja, akurasi aplikasi menjadi semakin menurun menjadi 85\%. Bahkan, jika jumlah masukan diturunkan lagi menjadi dua masukan, hasilnya semakin memburuk, yaitu $45 \%$. Program tetap dapat bekerja jika jumlah masukan hanya dua atau satu. Akan tetapi, hasilnya diperkirakan menjadi semakin tidak akurat. Hal ini dapat dipahami mengingat gejala yang terlalu sedikit menyebabkan kemungkinan penyakit semakin besar. Ini dapat diibaratkan seperti seorang dokter yang menganalisis penyakit pasien yang mana dokter tersebut perlu mengetahui banyak gejala penyakit agar dia dapat memastikan penyakit dengan lebih baik.

\section{KESIMPULAN}

Berdasarkan pembahasan di atas, maka dapat disimpulkan beberapa hal berikut:

1. Aplikasi "D-KIT" sudah berfungsi secara fungsional berdasarkan pengujian alpha.

2. Aplikasi D-KIT dapat melakukan prediksi jenis penyakit berdasarkan gejala-gejala yang dimasukkan ke dalam sistem ini dengan menerapkan algoritma Naïve Bayes.

3. Berdasarkan pengujian dengan data baru (data uji) aplikasi D-KIT memberikan hasil prediksi yang optimal, yaitu 95\%-100\% akurat dalam memprediksi penyakit jika masukan yang diberikan terdiri dari lima atau empat gejala. Jika masukan gejala hanya terdiri dari tiga gejala, maka tingkat akurasinya menjadi berkurang menjadi $85 \%$. Akurasi tersebut semakin berkurang menjadi $45 \%$ jika masukannya menjadi dua. Dengan kata lain, jika masukannya kurang dari tiga, maka hasil prediksinya akan semakin memburuk.

\section{DAFTAR PUSTAKa}

[1] Ayudhitya, D., \& Tjuatja, I. (2013). Health is Easy. Jakarta: Penebar Plus+.

[2] Bustami. (2013). Penerapan Algoritma Naive Bayes untuk Mengklasifikasi Data Nasabah Asuransi. TECHSI Vol 3, No 2: VOL III , 127.

[3] Irianto, K. (2015). Memahami Berbagai Macam Penyakit. Bandung: Alfabeta.

[4] Krishna, A. (2013). Mengenali Keluhan Anda: Edisi 1. Informasi Medika.

[5] Ostrander, J. (2012). Android UI Fundamentals: Develop and Design. Berkeley: Peachpit Press.

[6] Patton, R. (2001). Software Testing. Indianapolis: Sams Publishing.

[7] Rumbaugh, J., Jacobson, I., \& Booch, G. (1999). The Unified Modeling Language Reference Manual. USA: Addison Wesley Longman.
[8] Setiawan, W., \& Ratnasari, S. (2015, Februari 1). Sistem Pakar Diagnosis Penyakit Mata Menggunakan Naive Bayes Classifier. Retrieved Desember 30, 2015, from www.reseachgate.net: https://www.researchgate.net/publication/27 1605976_SISTEM_PAKAR_DIAGNOSIS_PENY AKIT_MATA_MRNGGUNAKAN_NAIVE_BA YES_CLASSIFIER

[9] Tan, P.-N., Steinbach, M., \& Kumar, V. (2006). Introduction to Data Mining. Boston: Addison Wesley.

[10] Techinasia. (2015, Januari 6). Android dan browser Opera dominasi pengguna mobile Indonesia selama 2014. Retrieved Desember 2, 2016, from id.techinasia.com:

https://id.techinasia.com/android-operadominasi-smartphone-indonesia-2014 